\title{
Role of Local Mass Media Control of Regional Governance in Indonesia (Case Study in East Nusa Tenggara)
}

\author{
Jonas Klemens Gregorius Dori Gobang ${ }^{1} \&$ Frans Salesman ${ }^{2}$ \\ ${ }^{1}$ Communication Studies Program at Nusa Nipa University, Jl. Health No.3 Maumere, Flores-East Nusa \\ Tenggara \\ ${ }^{2}$ Health Faculty at Citra Bangsa University Kupang-East Nusa Tenggara, Manafe Street 17 Kayu Putih-Kupang \\ Correspondence: Frans Salesman. E-mail: franssalesman@gmail.com
}

Received: July 22, 2019 Accepted: September 9, $2019 \quad$ Online Published: September 29, 2019

doi:10.5539/ass.v15n10p14

URL: https://doi.org/10.5539/ass.v15n10p14

\begin{abstract}
Background. Decentralization of the authority to manage government and regional development has been regulated in Law Number 32 of 2014 concerning Regional Government. However, in its implementation there are many deviations found in the form of corruption of local officials causing a loss of quality in human resources. The researcher tried to reveal the role of local mass media to control local governance so that its implementation did not cause corruption in the development budget carried out by regional government officials. Method and material. Using qualitative analysis of news texts published by local mass media with and content of corrupt behavior of regional officials in East Nusa Tenggara Province. Various secondary data is used to supplement this research information. Respondents of journalists and local media editor in chief. Results. Local media coverage revealed 100 regional heads were arrested and convicted of corruption. The impact of the worsening social conditions in the East Nusa Tenggara the high prevalence of stunting is $40.30 \%$; 2,669 infants with malnourished babies, 1,142,790 poor people (21.35\%) in 2018. Conclusion. It has been punished by regional officials who are perpetrators of corruption as a result of local media coverage. Corruption has a systemic impact on decreasing the quality of human resources in East Nusa Tenggara.
\end{abstract}

Keywords: mass media, corruption, governance

\section{Background}

Political reality in Indonesia has fluctuated from time to time. Only, the fact that is not denied after the collapse of the New Order government where the Indonesian political system has a more open style. The manifestation of freedom of opinion is implemented in press freedom. Previously the press was monitored by the government, after that there was a phenomenon about the strengthening of press control to the government (Parijan, 2010).

There are so many political issues that are of concern to the media. The relationship between media relations with the ideology and political dynamics of a country has been expressed by M. Roij, the former Chief Editor of de Nieuwe Rotterdamse Courant. According to him, the ideology that applies in the country where a newspaper or media is present and operates will gradually influence and determine the development of newspapers or media (Sularto, 2011).

What is the relationship between local media and authorities in the area? This question becomes important when Law number 23 at 2014 years concerning Regional Government in Indonesia applies full authority to regional authorities to regulate government and development in order to accelerate the realization of the welfare and prosperity of the people in their regions. However, the authority granted by the law was not carried out perfectly and even misused by the regional authorities to accumulate personal and family wealth. Much corruption has occurred in East Nusa Tenggara Province carried out by regional officials and some officials have been convicted and some are still in court proceedings. In that context, the presence of mass media is needed to monitor and evaluate the implementation of regional autonomy so that there is no deviation in the implementation of the authority granted by the regional autonomy law.

The role of local mass media and authorities in the region can be viewed from a communication and perspective. From a communication perspective, mass media see patterns of communication between institutions and or patterns of interpersonal communication based on local culture. From a fascist perspective, the relationship 
between the local mass media and the authorities in the region can be analyzed from the historical, economic, political and discourse contexts that develop (Martin et al., 2004). The purpose of this study is to analyze the extent to which the role of media in the role of local mass media controls local governance so that its implementation does not lead to corruption in the development budget carried out by regional government officials.

\subsection{The Problem}

How far is the role of local mass media in constructing news of deviations in the implementation of regional government, revealing corruption officials and their impact on the decline in the quality of human resources in East Nusa Tenggara? What is the relationship between mass media and the regional government system in Indonesia?

\section{Methods}

\subsection{Type of Research}

Using qualitative research through empirical observations on the practice of reporting printed local mass media in East Nusa Tenggara Province and analyzing the text and news content reported by various local mass media in East Nusa Tenggara Province. The researcher used the method of discourse analysis from Teun van Dijk which put forward three aspects, namely analysis of text, social context and social cognition (Van Dijk, 1993). Some information is obtained through literature review and publications of the East Nusa Tenggara Central Bureau of Statistics, and local and national mass media coverage.

\subsection{Research Objects and Subjects}

As the object of research is the news text and the production process of the news which becomes a headline about deviations in the implementation of government and development in the region. The research subjects as observation units are journalists as reporters, editors, owners of media and printed mass media institutions in East Nusa Tenggara Province.

\subsection{Data Collection Techniques}

The researcher collects data from interviews with journalists, news editors and media owners, then analyzes social cognition as suggested by Teun van Dijk in discourse analysis methods (Van Dijk, 1993) and pays attention to the historical context by determining the news on printed mass media in East Nusa Tenggara Province. This determination is based on epistemological criteria from a critical paradigm that emphasizes the concept of subjectivity where the values adopted by the researcher subjectively participate in determining the truth about something (Ardianto et al., 2007). Data collection techniques carried out by researchers in this study; collection of corruption news texts, interviews, literature studies and field observations.

\subsection{Research Validity}

The researcher conducted a data triangulation method by comparing data (cross check) obtained through interviews with the results of observations and literature studies and collection of documents. In addition, the researchers also used referential adequacy techniques by collecting a number of references from various sources. The consistency of observations was carried out by researchers to find the characteristics and elements related to the news process by the printed mass media in East Nusa Tenggara Province.

\section{Discussion}

\subsection{Corruption in Media Construction}

The social construction theory of reality states that reality is formed and constructed. The main thesis is individuals and society as a continuous dialectical, dynamic and plural product. Society is an individual product, on the contrary individuals are products of society. A person becomes a person who has an identity insofar as he stays in his community (Berger \& Luckmann, 1991).

The dialectical process has three stages of events; (1) externalization; (2) objectification; and (3) internalization. In the stage of externalization, individuals express themselves into the world, both in mental and physical activities as part of the basic traits possessed by humans. Humans find themselves in a world. Stages of Objectivation, namely the results of objective reality as a reality in the form of tangible manifestations. The stages of internalization, as the process of re-absorbing the objective world into consciousness in such a way that subjective individuals are influenced by the structure of the social world. Through internalization, humans become the results of society (Berger \& Luckmann, 1991).

Social construction theory of reality (Berger \& Luckmann, 1991) as a middle ground between social fact theory 
from Emilia Durkheim as something external, objective, and existent. Reality is a reality that can be treated objectively, because it is relatively permanent and shapes individual and social life. Whereas according to the view of social action theory, reality is seen as something internal and subjective. Reality is seen as a subjective reality that moves to follow the dynamics of individual subjective meaning. The above categories provide input that provides the subjective and objective foundation of each social phenomenon, so that the relationship between the two is dialectical from subjectivity to its objects.

Social construction theory over reality sees social reality as something that is in the social dialectic process, namely as objective reality and at the same time subjective which forms and is formed by society continuously. Corruption is an objective event that is now a community pathology in regional governance in Indonesia. The indications are that from 2004 to 2019 as many as 100 regional heads of 540 Regional Heads have been processed by the Corruption Eradication Commission and have been punished by judicial institutions in Indonesia. Corruption events also occur in East Nusa Tenggara Province. Until 2018, there were 3 Regional Heads who were convicted of corruption. The events of the capture of regional heads in corruption cases were due to public reports and mass media coverage which continuously covered the implementation of regional governance. The same applies to the news reported by a number of print media. The news is not an event that is actually the result of the interaction between journalists and facts that take place dialectically. Likewise when journalists conduct interviews with resource persons, there are interactions in the externalization process when reporters ask a number of questions to the resource person which is constructed in such a way as to produce news published by the mass media. So news on mass media is the result of construction of reality.

Every news is a fact constriction that really happens and is interpreted as a social reality by media workers and individuals who witnessed the event. Journalists and editors construct subjective reality that is in accordance with individual selection and preferences into objective reality that is displayed through the media by using symbols. This display of reality in the media is called symbolic social reality and is accepted by the reader as objective social reality because the media are considered to reflect reality as it is and are free from any interests. Preaching of mass media must be free from any interests (Susanto, 2013).

\subsection{Corruption and Local Mass Media}

Independent local mass media, encouraged by idealism and good management can be important entities in the region. Local mass media not only provide accurate information but are also able to provide political education for the people in the area. Local mass media become strong and have the capacity to oversee local governance.

The relationship between local media and the authorities in the area viewed from a communication perspective implies the existence of negotiation, creativity, renewal and challenges. From a critical perspective, the relationship between local media and authorities in the region can be analyzed from the historical, economic, political and discourse contexts that are developing (Martin et al., 2004).

News about corruption in East Nusa Tenggara Province is one of the focuses of local mass media. As a province including the top 10 poorest provinces in Indonesia, East Nusa Tenggara Province has a variety of corruption problems. Based on the mode; mark up $24 \%$, manipulation of $21.60 \%$, embezzlement of $20 \%$, misuse of budget $13.60 \%$, enriching oneself / others $10.40 \%$, work on projects not in accordance with the best $8 \%$, and mark down $2.4 \%$ (Ama, 2010). As the media reports on the ranking of corruption by province in Indonesia, where five major provinces with consecutive corrupt ASNs, 298 people from North Sumatra, 193 people from West Java, 190 people from Riau, 183 from East Nusa Tenggara, and 146 from Papua (Rescue, 2019). Facing the poor reality and corruption, the presence of local mass media is important. Local mass media is known and read by the people in East Nusa Tenggara, is expected to play its role, not only in providing information but also can take the attitude of control from civil society on the path of regional government. The attitude of the local mass media can be found in editorial rubrics. This rubric conveyed a straightforward attitude from a media institution to the phenomenon, issue, or fact that was happening in the community.

Editorial rubric presentation and news published by local mass media is a form of control of local government policies. Sometimes conflicts occur because the local government considers local media coverage to be too agitative and excessive from the actual facts. News about corruption has always been considered sensitive and provocative by local government officials. The topic of corruption and poverty has always been a trending topic decorating the first page of the newspaper. Corruption reporting touches the privacy and good name of the regional government apparatus. Tensions and conflicts occur because the identification of facts by local media to broadcast news in the mass media may not be based on scientific methodology, or in other words based on the subjective assumptions of journalists. From the facts about the frequency of reporting, cases of corruption and poverty are the most popular news in the present (Martin \& Nakayama, 2004). 
Corruption for the people in East Nusa Tenggara Province has become a scourge. Even corruption is not only chronic pathology, but also ironic because it occurs in areas that are classified as poor. It's like falling over the stairs. Poor, corruption also (SinlaEloE, 2010), as a result of corrupt actions carried out by state budget managers, the low amount of the budget should be felt by the community. Impact on the deterioration of social conditions in the East Nusa Tenggara region, such as; (1) there is still a high prevalence of stunting in infants under five in East Nusa Tenggara reaching $40.30 \%$, the highest compared to other provinces in Indonesia. At the same time, the national stunting prevalence was $29.60 \%$. The prevalence of stunting in East Nusa Tenggara consists of babies with very short categories of $18 \%$ and short $22.30 \%$ (McNair, 2003); (2) there were 2,659 infants in 2016 with malnutrition, 3,072 in 2017 and 2,669 babies in 2018 (Rescue, 2019); and (3) The poverty rate in Nusa Tenggara province is still relatively high. The number of poor people in 2016 was $1,149,920$ people (22.19\%), in 2017 there were 1,150,790 people (21.85\%), and in 2018 1,142,170 people (21.35\%) (Putra, 2018).

Actors of corruption in East Nusa Tenggara vary. Generally the perpetrators are upper middle class, namely local government officials (governors, mayors / regents, heads of offices, sub-district heads, village heads and other regional government staff), DPRD members, police, prosecutors, judges, political party administrators, entrepreneurs even teachers and school principals are involved in the problem of corruption in East Nusa Tenggara. Local mass media in East Nusa Tenggara Province has legality as a press institution for every problem that occurs at the local, regional, national and international levels. But what researchers want to examine and study more deeply is the attitude of the two regional newspapers dealing with the problem of corruption that occurred in East Nusa Tenggara Province.

The problem of corruption in the East Nusa Tenggara region is always raised in the news and in the editorial rubric of the local print mass media. Local print mass media want to show their attitude that clearly rejects corruption practices in all its forms and whoever they are, both at the regional (district) and provincial level. With this, the local print mass media is committed to showing an attitude of rejecting corrupt practices in East Nusa Tenggara while aiming to sensitize the reader that corruption in any form must be rejected in East Nusa Tenggara.

The attitude of the local printed mass media as a media institution (regional press) against corruption in East Nusa Tenggara is to strongly oppose the act of corruption as a form of crime against the people who increase people's poverty. The local print mass media is also straightforward and firm in defending the interests of the people and encouraging the law enforcement process for corrupt actors (corruptors) who are officials in the regions, both executive and legislative.

\subsection{Restoring the Rights of the People}

The local print media continued to put pressure on the despotic authorities boldly to preach the various corruptions and deviations of the power they had made. This aroused people's awareness of their rights which had been annexed by the authorities and raised resistance against the dictatorship of power. The people can come out of the cage of oppression and breathe oxygen of freedom and independence. Edmund Burke emphasizes this fact by stating that the media represent an independent source of knowledge that not only informs the public about political activities, but also protects the people from abuse of power and investigate various policies and acts of abuse of power carried out by political elites and authorities who want to be covered up or hidden so that the people continue to demand moral, political and legal responsibility from them. At present there is no dilapidation in public affairs that is hidden because at some point the media will surely dismantle it. It must be admitted that the success story of the people's struggle overthrew dictators in various parts of the world and the uncovering of the various depravity of power in this country is the success story of the role played by the media.

Local mass media as institutions and media workers as subjects must continue to present themselves as free and independent news processors accompanied by moral courage not to be "paid" by the owners of capital and power holders. Local media must work with certain principles so that accountability can be measured by the community and authorities in the region.

Critical perspectives in transultural communication (intercultural communication) help us to see more deeply about the relations between local media and authorities in the region. This critical perspective encourages the investigation of marginalized groups or groups that are oppressed and tests the power used in intercultural relations (Susanto, 2013). The following is the scheme of relations between local media and authorities in the regions after the passage of the Regional Autonomy Law. 
Scheme of the Relationship between Media Systems and Government Systems

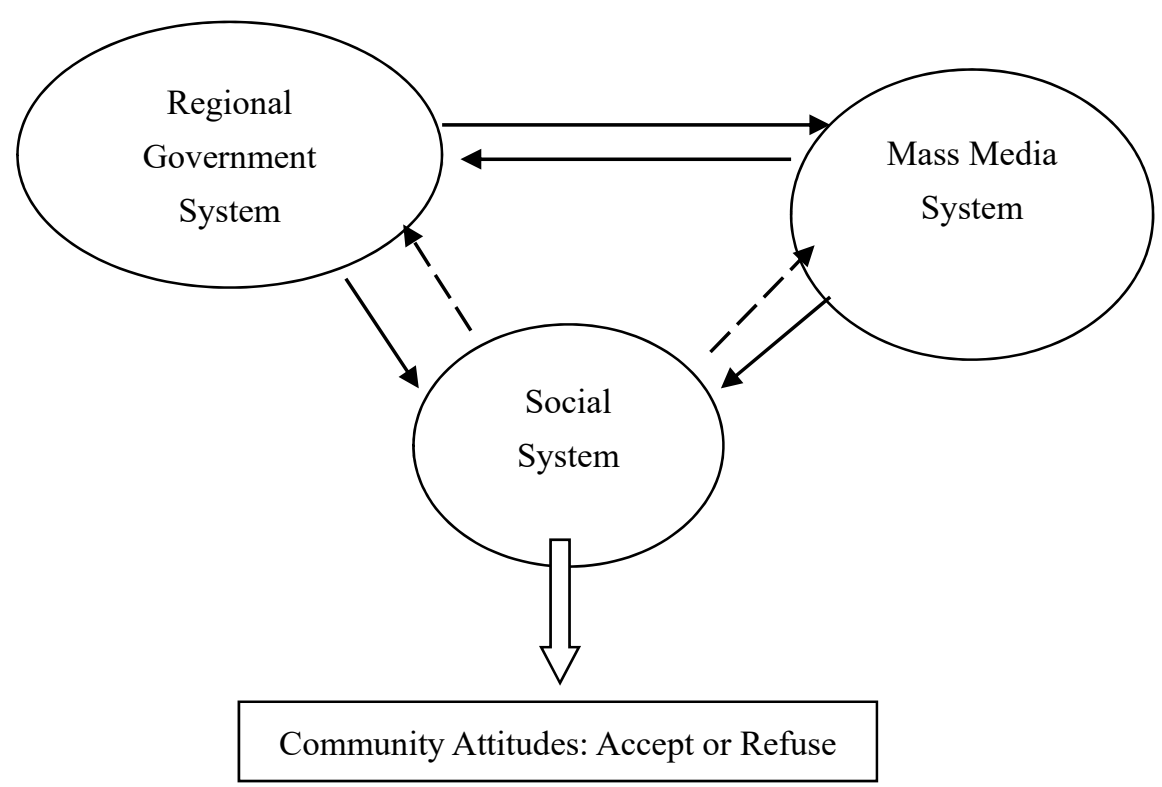

Explanation: Between political realities in the region and the local media system, both have mutually influential relationships. A political reality that arises can affect the media system. Thus even the media system can construct political reality and even form a new political system (from an authoritarian system / guided democracy to a more open / democratic system). Both the political system and the media system, both are able to influence the social system. New social institutions are formed, such as the civil society movement, workers, campus activist groups, and others. This social system will influence the attitude of the community / public. Communities can determine their attitude, accept or reject government programs or certain figures in political circles. The social system will be able to influence the media system and political system, but its influence is less firmly indicated by an arrow with a dotted line. In Indonesia, the media system and political system are very dominant affecting the social system. The concept of ideology as a false consciousness can be played by the media and rulers.

\section{Conclusion}

Local mass media should act as a social instrument that enlightens citizens to be smart and critical of building substantive democracy in the regional government system who are vulnerable to corrupt behavior, if local mass media as social capital to continuously control corrupt behavior in governance in the region.

The role of the local mass media always proclaims the text and content of news of abuse of authority and corruption of regional officials has resulted in a decrease in the degree of public health and the quality of human resources in East Nusa Tenggara. Local mass media is a channel used to restore the rights of the people of East Nusa Tenggara who have been seized by corruptors.

The ability of local mass media to preach the essence of regional autonomy to restore people's rights and encourage good local governance in the future, as well as increase the professionalism of regional officials in implementing clean and authoritative governance, free from corrupt behavior.

\section{Acknowledgment}

Appreciation are given to; (1) Chancellor of the University of Nusa Nipa who has given space and time for the author to write this scientific article; (2) Editor in Chief of the Local and National Period Media as resource persons and the East Nusa Tenggara Province Central Bureau of Statistics who have presented secondary data; (3) Fellow lecturers at the Nusa Nipa University Communication Studies Program who have helped complete the writing of this article.

\footnotetext{
Abbreviations

DPRD = Regional People's Representative Council

Law $=$ Law (law, regulations)

ASN = State Civil Apparatus (State Civil Apparatus)
} 


\section{Conflict of Interest}

The author has no freedom and conflict of interest at this writing. There is no harm to his privacy as a public official in the publication of this article in a journal that is willing to publish it.

\section{References}

Ama, K. K. (2010, May 25). East Nusa Tenggara Regional Autonomy; Octopus Corruption in Poor Regions. Retrieved July 9, 2019, from https://antikorupsi.org/.../otonomi-daerah-EastNusaTenggara-gurita-korupsidi-daer...

Ardianto, Elvinaro, \& Q-Anees. (2007). Philosophy of Science. Retrieved July 9, 2019, from https://elib.unikom.ac.id/download.php?id=190921

Berger, P. L., \& Luckmann, T. (1991). The Social Construction of Reality: A Treatise in the Sociology of Knowledge (pp. 232-233). Great Britain: Penguin Books.

BPS of East Nusa Tenggara Province. (2019). East Nusa Tenggara in 2018. Retrieved July 11, 2019, from https://East Nusa Tenggara.bps.go.id/.../2018/.../jumlah-bayi-gizi-buruk- according to-...

Littlejohn, S. W., \& Foss, K. A. (2009). Encyclopedia of Communication Theory (p. 123). California: Sage Publications.

Martin, J. N., \& Nakayama, T. K. (2004). Intercultural Communication in Contexts. New York: The McGraw-Hill Companies.

McNair, B. (2003). An Introduction to Political Communication (3rd ed.). New York: Routledge.

Ministry of Law and Human Rights of the Republic of Indonesia. (2014). Law Number 23 Year 2014 concerning Regional Government. Retrieved July 9, 2019, from https://www.hukumonline.com/.../undang-undang-nomor-23-tahun..

Parijan, K. (2010). Indonesian Political System, Consolidation of Post-New Order Democracy (p. 120). Jakarta. Kencana Prenada Media Group.

Putra, D. B. (2018). The Stunting Prevalence in East Nusa Tenggara is the Highest in Indonesia. This is the cause. Pos Kupang. Com.6 November 2018. It is dated July 11, 2019. Retrieved from https://kupang.tribunnews.com >Regional East Nusa Tenggara $>$ Flobamorata

Rescue, L. (2019). East Nusa Tenggara Poverty and ASN Corruption. Pos Kupang Opinion October 072018. Retrieved July 11, 2019, from https://kupang.tribunnews.com > Editorial > Opini

SinlaEloE, P. (2010). Corruption and Eradication in the Poor Province. It was delivered at the National Anti-Corruption Youth Symposium with the Theme: Strengthening the Youth Spirit in Realizing Clean Governance. Organized by the Anti-Corruption People's Movement (GeRAK) Indonesia Collaboration with the Ministry of Youth and Sports. Hotel Atlet Century Park, Jakarta, October 25, 2010.

Sularto, S. (2011). Thankful There Is No End, Jakob Oetama's Step Footprint (Jakarta: p. 121). Gramedia Kompas Publisher.

Susanto, E. H. (2013). Mass Media, "Government and Owner of Capital". Journal of Communication, 1.

Van Dijk. (1993). Principles of Critical Discourse Analysis. Retrieved July 9, 2019, from http://journals.sagepub.com/doi/abs/10.1177/0957926593004002006

\section{Copyrights}

Copyright for this article is retained by the author(s), with first publication rights granted to the journal.

This is an open-access article distributed under the terms and conditions of the Creative Commons Attribution license (http://creativecommons.org/licenses/by/4.0/). 